\title{
OBITUARY
}

\section{Michael John Tomlinson}

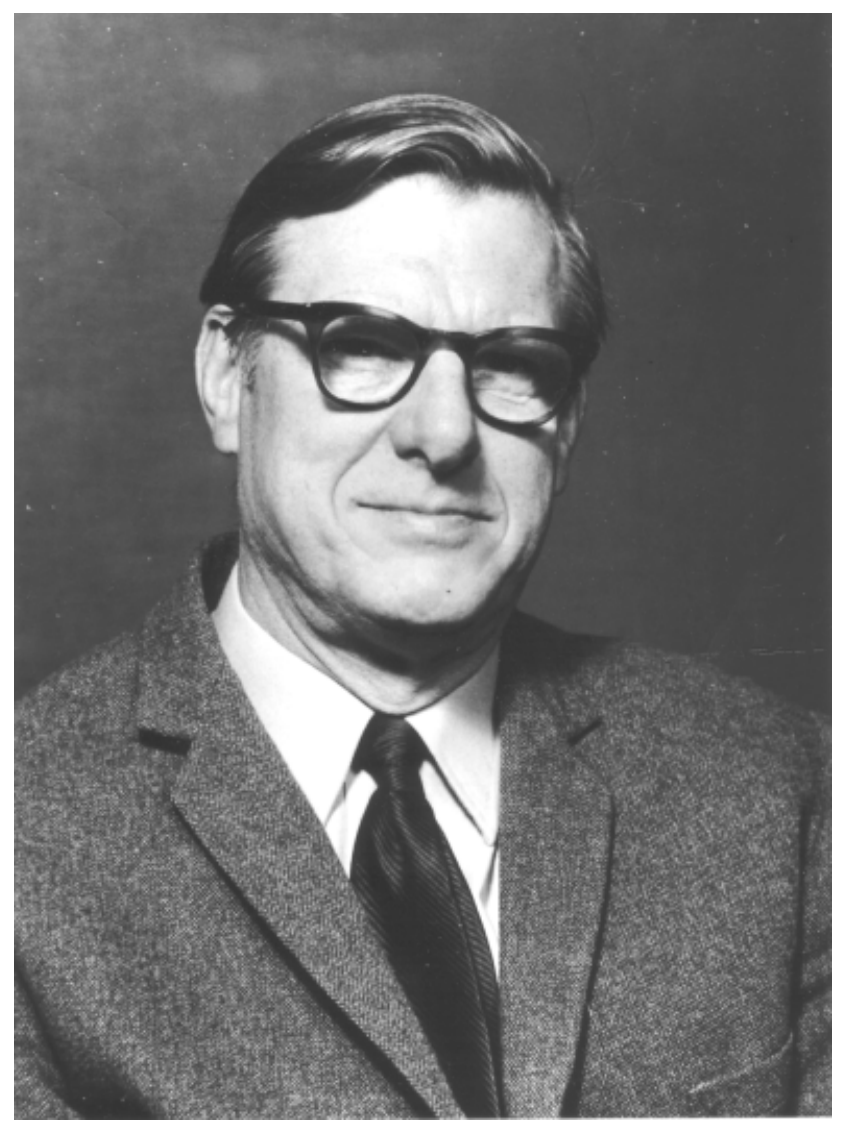

Michael John Tomlinson, 1916-2011

Michael John Tomlinson, who died on 8 February 2011 aged 95, was an eminent civil and structural engineer, who made a huge contribution to the science of soil mechanics and the practicalities of geotechnical engineering in the UK and overseas for over 60 years. He investigated and designed foundations for marine jetties, bridges, buildings, tunnels and dams and was instrumental in devising and employing innovative techniques for examining the properties of soils and rock. His technical writings are still at the heart of many foundation designs and were used to develop the relevant British Standards for many years.

Tommy, as he was known to friends and colleagues throughout the geotechnical industry, was born on 21 January 1916 at Scunthorpe. His father was estate manager at Normanby Hall. He was educated at Scunthorpe Grammar School and started his long career in 1934 as an articled pupil to W. Farrar, borough engineer of Scunthorpe Corporation. After four years, he became an engineering assistant with Middlesex County Council and studied part-time for the professional engineering examinations.

During wartime service he was seconded to the Air Ministry Directorate-General and commissioned flight lieutenant, designing and supervising construction of roads and airfields, first in the UK then the Near East, based in Jerusalem. After the war he spent a year with Middlesex and Surrey County Councils in the highways and bridges departments.
In 1947 he joined the central laboratory of George Wimpey \& Company, then the largest construction contractor in the UK. In the 1940 s, soil mechanics had been largely developed by academic institutions, but now the major construction companies were setting up specialist departments to carry out field and laboratory investigations, analyse the results and produce the engineering reports. Tommy played a major part in developing an outstanding team of specialist engineers, geologists and geophysicists who worked on the geotechnical aspects of many projects undertaken by the parent company. With his guidance as Chief Engineer and then Technical Director, the expertise gained in several thousand site investigations, in foundation design, engineering geology and other advisory work, was successfully applied to commercial work for contractors and consultants worldwide, under the banner of Wimpey Laboratories Ltd.

The list of projects on which he had a major input with Wimpey is considerable - docks and harbours, oil refineries, offshore oilfield developments, highways and bridges and power stations - and the locations were as varied. The large Harland and Wolff dry dock in Belfast, the covered dock for Appledore Shipbuilders in Devon, Karachi docks, Bandar Abbas in Iran and a dry dock for Niarchos in Scaramangar, Greece were notable. His knowledge of groundwater control was key to the construction of the dry dock at Nigg bay on the Cromarty Firth for the fabrication of the first large oil production platform for the BP Forties Field in the North Sea. Here, the earth side slopes of the excavation were stabilised with an extensive system of pumping from deep and shallow wells around the perimeter to prevent groundwater and tidal water seeping through the side slopes causing failure.

His work for the Air Ministry had given him a keen interest in the Middle East and when the parent company was undertaking construction of oilfield developments in the area he was a regular visitor to Aden, Abu Dhabi, Kuwait and Iran, giving advice on jetties and large tank farms. He also worked on oil-related works in Baghdad, the Niger delta, Sumatra and Trinidad for consulting engineers. One of his longest road jobs was on the Baghdad to Basra highway and he dealt with investigations for road bridges over the River Tay, the River Humber and the Samarra Bridge over the Tigris in Iraq. He initiated many techniques for ground investigation including down-the-hole inspections and in situ strength testing in the sides of boreholes. With Harold Harding of Soil Mechanics, he was instrumental in bringing to the UK the 'sparker' echo-sounder, developed at Woods Hole Oceanographic Institute in the USA, for use on the first marine investigations for the new Channel Tunnel in 1952, producing a detailed profile of the sub-seafloor geology.

When he retired from Wimpey in 1976, he set up in private practice as a consulting engineer to advise civil and structural consulting firms, architects and contractors on geotechnical engineering and to produce expert witness reports for construction litigation in the High Court. Again he dealt with an eclectic mix of subjects and locations, among them - the Jeddah to Mecca Expressway, sinking the caisson for the Torridge River Bridge, a preliminary foundation design for the Rion-Antirion bridge in Greece, piling 
to container berths in Java, foundation construction on the Hong Kong Shanghai Bank and the $83 \mathrm{~m}$ long piles for the Jamuna River bridge in Bangladesh.

He was author of two highly influential textbooks on foundations based on his extensive experience as contractor and consultant - Pile Design and Construction Practice, now in the fifth edition, and Foundation Design and Construction, which went to seven editions - both considered classics and used by designers and contractors throughout the world. He contributed to the Proceedings and written discussions of the Institution of Civil Engineers on a wide variety of subjects in over 100 papers from 1946 onwards and his work is cited in many more. Several papers dealt with airfield and road construction following on from his wartime experience, but other topics included site investigations, piled rafts, the Furnas hydro-electric tunnels under the dam in Brazil, where methane was a major problem, and oil jetties in the Persian Gulf. Among a number of articles published in Géotechnique, he wrote a review of Thomas Telford's work in the development of soil mechanics.

Michael Tomlinson was elected Fellow of the ICE in 1958 and Fellow of the Institution of Structural Engineers in 1972 and was Chairman of the British Geotechnical Society (BGS) from 1969 to 1971. In 1988 he was the recipient of the Skempton Gold Medal of the BGS for his major contributions to the practice of geotechnics in the UK over a sustained period. He received the Coopers Hill Memorial prize from the Institution of Civil Engineers (in memory of engineers lost in the First World War) in 1958 for a definitive paper on airfields on overseas soils. In 1978 he was awarded the Oscar Faber bronze medal from the Institution of Structural Engineers with Burland and Driscoll of the Building Research Station. His committee work for the British Standards Institute was extensive and effective over many years, where he served as chairman for the code of practice on earthworks and as a member for codes on earth retaining structures and foundations. He also served on the British National Committee of the International Society of Soil Mechanics and Foundation Engineering and the advisory committee of the Transport and Road Research Laboratory, all at a critical time when new investigation techniques were being developed. He lectured widely and was an external examiner for several universities.

He was a thoughtful, unassuming man and generous in sharing his knowledge. He was always approachable, particularly in giving time to encourage younger members of staff and helping with on-the-job training, having himself climbed the professional ladder the hard way. He had a lifetime interest in socialist politics, and was an avid reader. $\mathrm{He}$ enjoyed gardening and was an accomplished garden designer. His wife, Elizabeth, predeceased him in 1999. His two daughters survive him.

John Woodward 